\title{
DIE ROL VAN DIE SUID-AFRIKAANSE WEERMAG IN NATUUR- EN OMGEWINGSBEWARING
}

\author{
Mev. W. Kleyn* \\ (met erkenning van Maj. S.K.B. Godschalk)
}

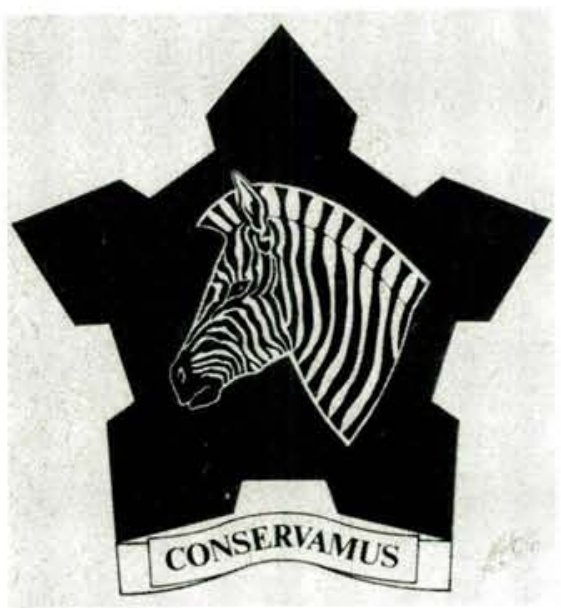

As the South African Defence Force has a responsibility towards the country to manage and conserve the natural environment entrusted to its care to the best of its ability, it is only fitting that the article below is dedicated to the role of the South African Defence Force in animal, environmental and nature conservation.

\section{Inleiding}

Die Suid-Afrikaanse Weermag se primêre doel is die verdediging van die Republiek van SuidAfrika en sy inwoners. Om hierdie doel te kan bereik, het die Weermag ' $n$ groot aantal opleidings- en toetsterreine, met ' $n$ totale oppervlakte van meer as 525000 hektaar grond, onder sy beheer.

Omdat militêre opleidings- en ander bedrywighede ' $n$ groot invloed op die natuurlike omgewing kan hê, is dit noodsaaklik dat sulke bedrywighede ekologies korrek beplan en uitgevoer word en dat die terreine ekologies korrek bestuur word, om sodoende te verseker dat die opleidingsterreine op die lang termyn geskik bly vir opleiding en nie onherstelbaar beskadig word nie. Verder het die Weermag ' $n$ verantwoordelikheid teenoor die land om die natuurlike omgewing wat aan sy sorg toevertrou is, korrek te bestuur en te bewaar vir die nageslag.

\section{Agtergrond}

Omgewingsbewaring was nog altyd deel van die militêre tradisie, hoewel daar eers in 1977 deur die huidige Minister van Verdediging, genl M.A. de M. Malan, opdrag gegee is om dit op ' $n$ meer georganiseerde wyse aan te pak. Kort daarna, in 1978, het die eerste Weermagorder mbt natuur- en omgewingsbewaring die lig gesien. Dit is in 1981 opgevolg met ' $n$ publikasie waarin die Weermag se beleid en prosedures in dié verband uiteengesit is, wat jaarliks hersien word.

Natuur- en omgewingsbewaring in die Suid-Afrikaanse Weermag word op 'n gedesentraliseerde wyse uitgevoer. Die uitvaardiging van die beleid, prosedures en riglyne, die hoë vlak skakeling met buite-instansies asook sekere spesialisfunksies is die verantwoordelikheid van die seksie Ekologiese Dienste by Afdeling Logistiek. Dié seksie se hoofdoel is "om die ekologiese geskiktheid van weermagterreine vir volgehoue militêre benutting te verseker"

Dit beteken dat militêre bedrywighede so beplan word dat die minimum versteuring van die natuurlike omgewing veroorsaak word en dat moontlike versteurings van die omgewing wat onvermydelik is, so ver moontlik herstel word. As deel van enige beplanningsproses moet veral 
die ekologiese faktore in aanmerking geneem word. Dit sluit beplanning in die algemeen, verkryging van nuwe terreine en uitbreiding van. bestaande terreine tot die beplanning van nuwe of uitbreiding van bestaande ontwikkelings of aktiwiteite in.

Korrekte ekologiese bestuur (natuurbewaring) word op al die militêre terreine toegepas om hul geskiktheid vir volgehoue opleiding te verseker en omdat alle militêre terreine as bewaringsgebiede beskou word. 'n Ekologiese bestuursplan word vir elke terrein opgestel. In dié plan word 'n volledige beskrywing van die terrein en al sy natuurlike bates gegee. Verder word alle huidige en beoogde militêre gebruike van die terrein beskryf asook die moontlike invloede daarvan op die omgewing. Dan word die bewaringspotensiaal van, asook bestaande en voorsiene ekologiese probleme op die terrein ontleed waarna 'n bestuursdoel en ondersteunende doelstellings geformuleer word. Volledige voorskrifte vir die bestuur van die terrein insluitende 'n grondgebruiksewewig, word gegee wat dan uitloop in 'n gedetailleerde doelwitprogram (vyfjaarplan) wat ook navorsing en monitering insluit.

Die bestuursplanne moet gereeld hersien word om by veranderde omstandighede aan te pas. Al die aspekte van ekologiese bestuur geniet aandag soos byvoorbeeld bewaring van inheemse plante- en dierelewe, bodembewaring en gronderosie, watervoorsiening, heinings, brandbeheer, hervestiging van inheemse wild en plante, uitroei van uitheemse diere en plantegroei, veldbestuur, 'n beheerde brandprogram, uitdun van oortollige wild om oorbeweiding te voorkom en bekamping van alle vorme van besoedeling.

Navorsing speel 'n groot ondersteunende rol in korrekte ekologiese beplanning en bestuur. 'n Belangrike onderwerp vir navorsing is die ekologiese invloede van verskillende militêre bedrywighede en hoe om enige nadelige invloede te verminder.

Die Suid-Afrikaanse Weermag skakel nou met 'n aantal professionele liggame asook met die natuurbewaringsliggame van die vier provinsiale administrasies. Dit is ' $n$ permanente lid van die Nasionale Komitee vir Natuurbewaring, dien in die Adviserende Komitee vir die Nasionale Diploma in Natuurbewaring aan die Pretoriase Technikon en in verskeie komitees van die W.N.N.R. Daar word ook nou saam gewerk met ander departemente, privaatorganisasies en individue.

Uit erkenning vir die werk wat đie SAW vir natuur- en omgewingsbewaring gedoen het, het die Trust vir Bedreigde Natuurlewe in 1981 erelidmaatskap aan die Weermag toegeken.

In 1983 het dieselfde Trust asook Caltex twee wisseltrofeë vir Natuur- en Omgewingsbewaring, onderskeidelik, aan die Weermag geskenk vir jaarlikse toekenning aan die eenheid wat die. beste gevorder het tov dié aspekte. In 1987 het die Nasionale Veldtrust 'n soortgelyke trofee vir omgewingsopvoeding geskenk.

As deel van die Suid-Afrikaanse Weermag se beleid om natuur- en omgewingsbewaring te bevorder, is Vhembe in 1967 as privaatnatuurreservaat verklaar, gevolg deur Corbadraai in 1979, Hoedspruit in 1981, Snake Valley en Vaalbank in 1985. Sekere terreine is ook tot natuurerfenisterreine verklaar: in 1985 Heidelberg en in 1987 Vhembe, Vaalbank, Klawervallei en 6BKD. Tans word daar met die Nasionale Parkeraad en die Transvaalse Afdeling Natuurbewaring onderhandel oor gesamentlike natuurbewaringsprojekte te Riemvasmaak en Corbadraai, onderskeidelik.

\section{Bewaring van Plantegroei in die Suid- Afrikaanse Weermag}

Militêre terreine maak ongeveer $7 \%$ van SuidAfrika se bewaringsgebiede uit waarop 'n groot verskeidenheid veldtipes en habitatte dwarsoor die land bewaar word. Die bewaring van die grond vorm die grondslag vir enige bewaringspoging. Daarom word gronderosie aktief voorkom en beheer. Natuurlike plantegroei word beskerm en waar nodig hervestig.

Spesiale maatreëls word getref vir die bewaring van skaars plantsoorte. Op een van die Kaapse terreine kom daar byvoorbeeld 'n heidesoort (Erica heleogena) voor wat nêrens anders ter wêreld aangetref word nie. Op dieselfde en verskeie ander terreine kom heelwat skaars plantsoorte voor. Vir die beskerming van die natuurlike plantegroei is dit verder nodig dat uitheemse indringerplante bekamp word. Groot sukses is al op talle terreine hiermee behaal.

Aandag word ook aan veldbestuur geskenk wat gereelde veldbrandprogramme en die bestryding van bosindringing insluit. 


\section{ald}

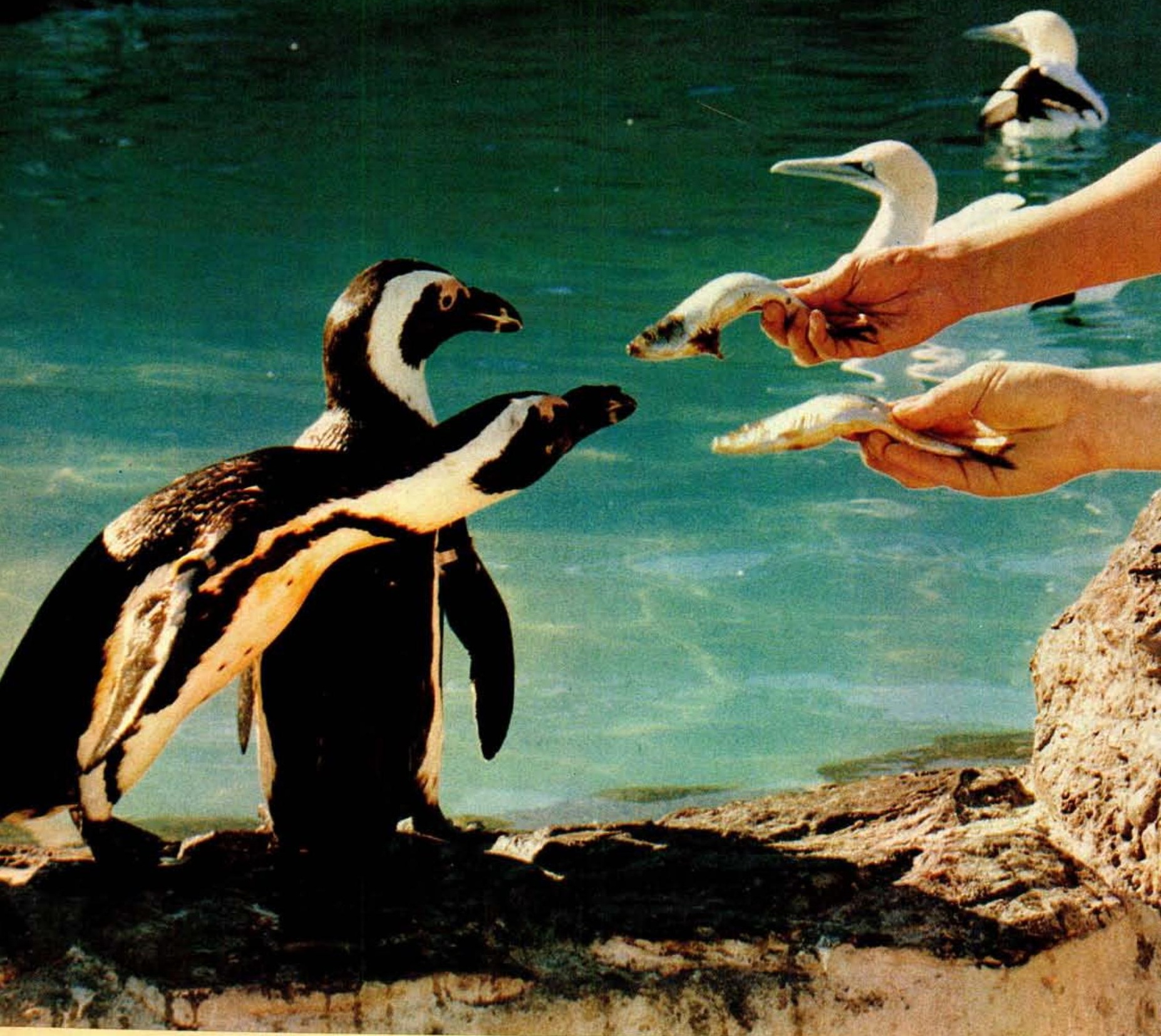

Twee bevare seemanne besig om pikkewyne te voer by die SA Nasionale Stigting vir die Bewaring van Kusvoëls te Bloubergrant.
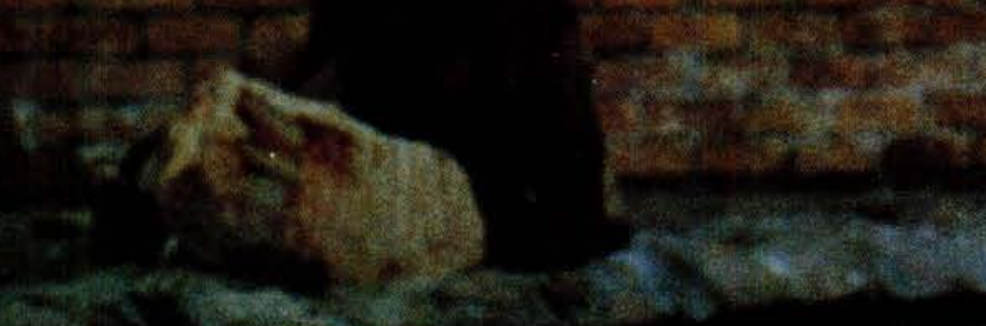


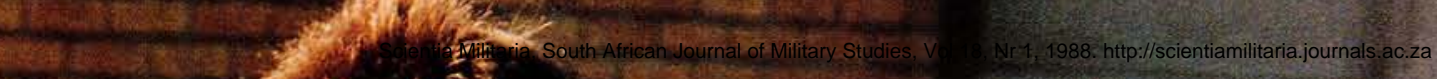

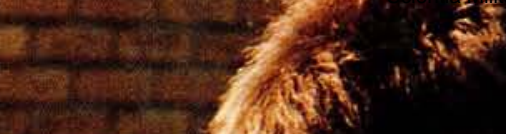

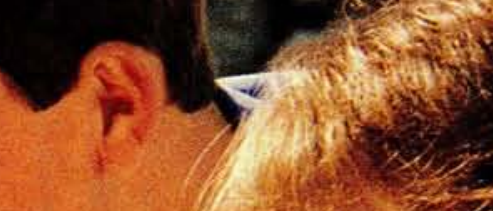

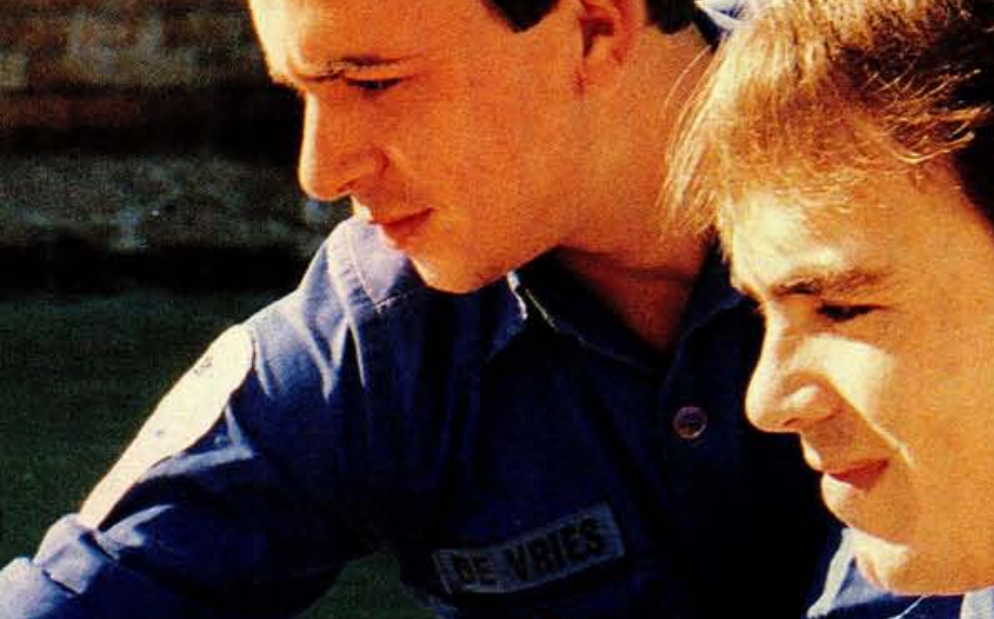




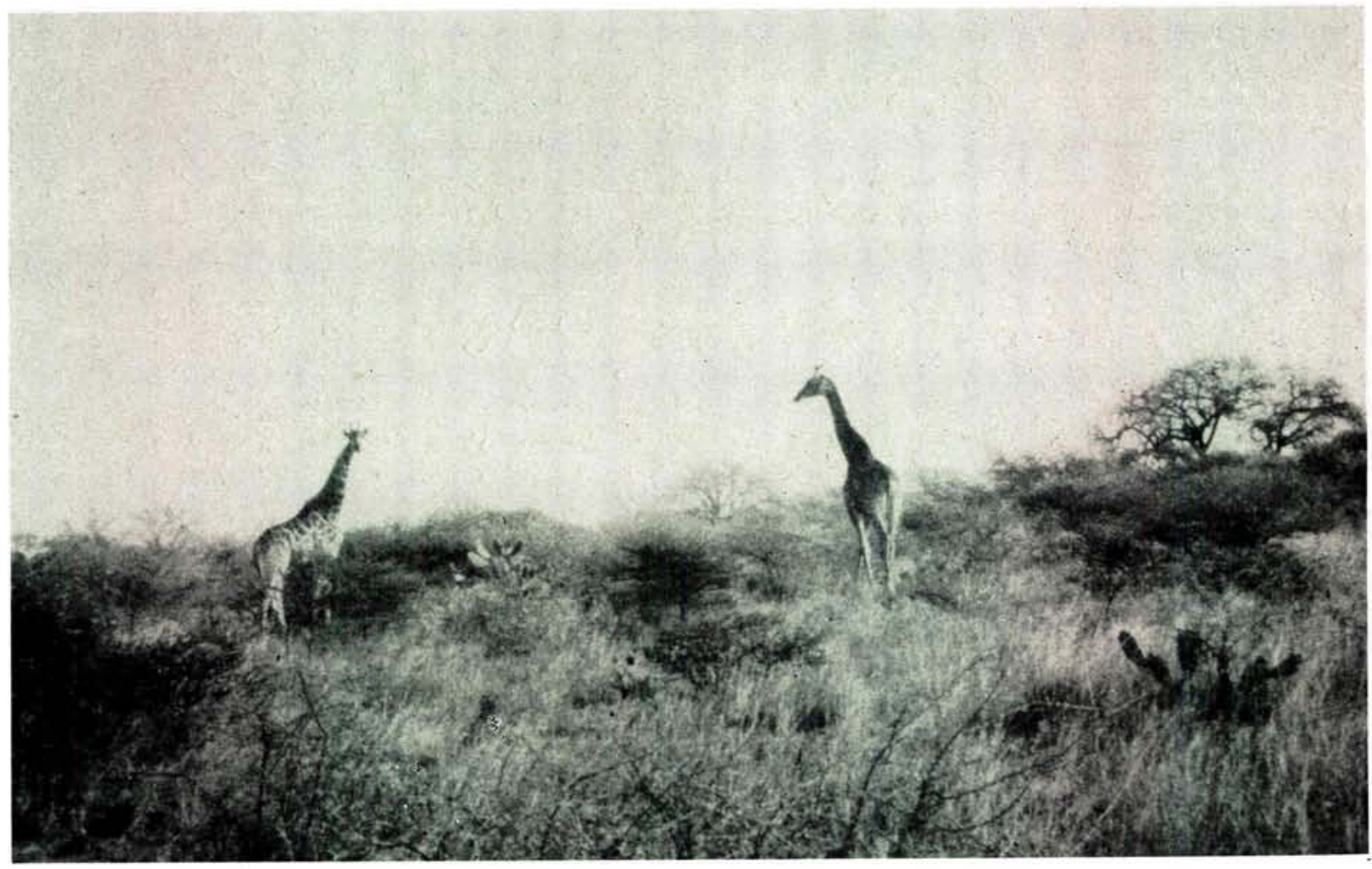

Kameelperde wat vanaf LMB Hoedspruit na Corbadraai hervestig is.

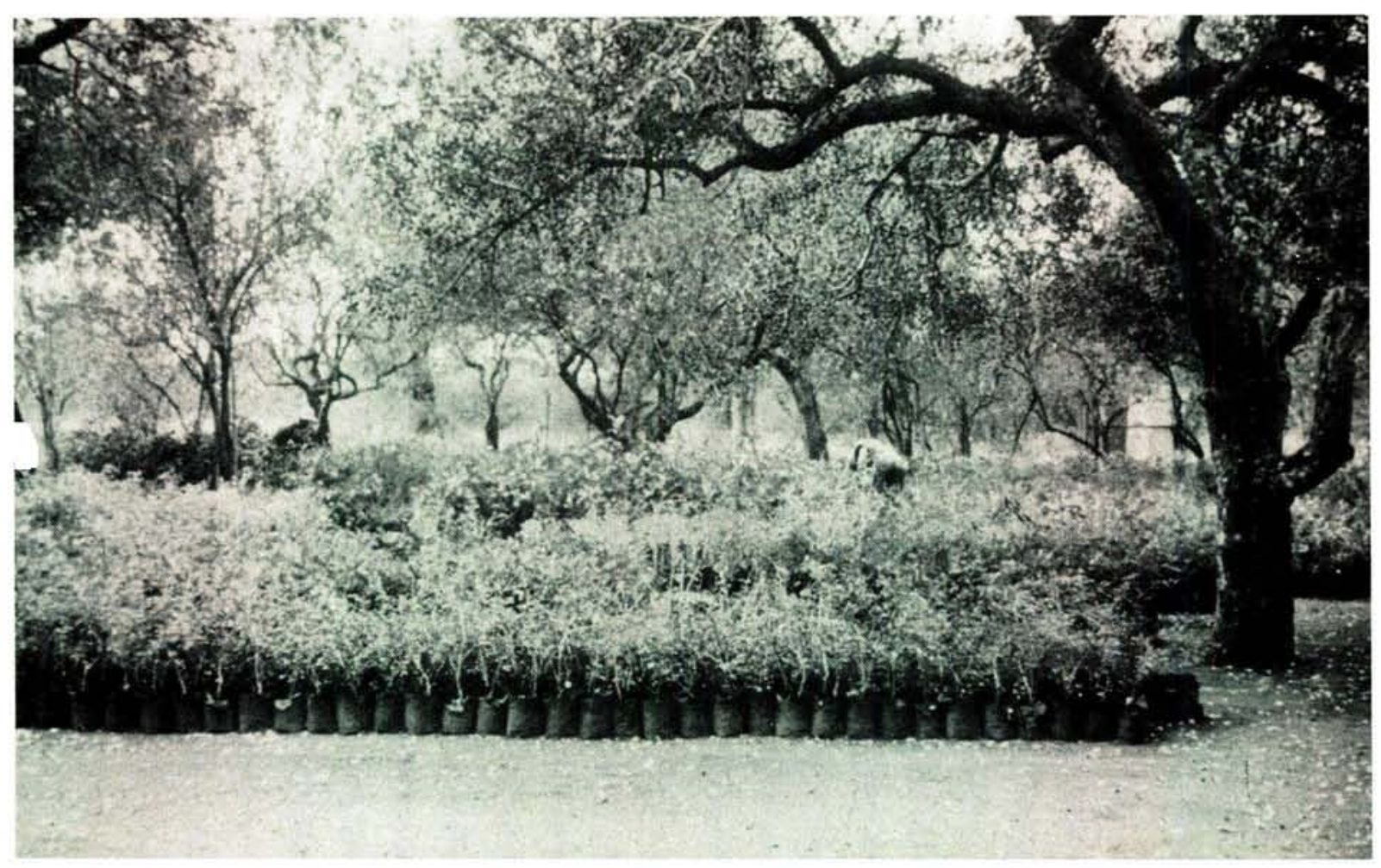

Inheemse boomkwekery op Hoedspruit om versteurde gebiede weer te beplant. 
Omtrent ' $n$ derde van Suid-Afrika se plantkundige veldtipes is op militêre terreine dwarsdeur die land verteenwoordig. Sodoende lewer die Weermag 'n groot bydrae tot die bewaring van verskeie veldtipes. In sekere veldtipes kom meer as die helfte van, of selfs alle, bewaarde grond op militêre terreine voor.

Die Suid-Afrikaanse Weermag speel ook 'n groot rol in die uitroei van verklaarde onkruide. Die vernaamste indringerplante in Suid-Afrika is feitlik sonder uitsondering uitheemse plante wat veral vanuit Suid-Amerika ingevoer is. Dit is ook nie algemeen bekend nie, maar gedurende die Tweede Vryheidsoorlog is sade van onkruidsoorte soos die Nasella-saadtandgras saam met voerbale die land ingebring. Dit is dus duidelik dat, sover dit die natuurlike habitat van 'n land aangaan, daar 'n groot verantwoordelikheid op militêre instansies rus.

\section{Bewaring van dierelewe in die Suid- Afrikaanse Weermag}

Alle militêre terreine van die Suid-Afrikaanse Weermag geniet ' $n$ hoë mate van beskerming deur streng sekerheidsmaatreëls en beheer oor personeel en aktiwiteite. Daardeur word wildstropery en onwettige beweiding deur vee en versteuring deur oortreders aan bande gelê. Dit het reeds gelei tot ' $n$ aanmerklike verbetering in veldtoestande en wild- en voëlgetalle op talle terreine nadat dit deur die Weermag oorgeneem is.

Dit is die beleid van die Weermag dat die dierelewe so min as moontlik versteur word. Inheemse diere word weer hervestig en uitheemse diere verwyder. Oortollige wild word of elders hervestig as daar ' $n$ behoefte is of by ander instansies geruil vir skaars diersoorte wat in hul historiese gebiede hervestig kan word. As daar geen ander uitweg is nie, word hule geskiet.

'n Interessante verskynsel is die gebruik van valke deur die Suid-Afrikaanse Lugmag by die Lugmagbasis Waterkloof. Aangesien vliegveiligheid die belangrikste prioriteit van die Lugmag is, kan 'n enkele voël ' $n$ noodlottige ongeluk veroorsaak. By Waterkloof word valke deur valkeniers opgelei om ander voëls te verwilder. Die Lugmag spog tans met ten minste 2 edelvalke en 'n swart sperwer om voëls, veral dié wat oor die aanloopbaan beweeg, van kant te maak of te verwilder. Die valke beskik oor ' $n$ natuurlike behendigheid en wanneer hulle nie ander voëls dood nie, dien hulle as afskrikmiddel.
Natuurbewaring in die Weermag behels ook die beskerming van skaars wildsoorte soos swartwitpense, basterhartbeeste, bastergemsbokke en witrenosters wat by Hoedspruit en Corbadraai naby Pietersburg voorkom. Verskeie eksperimente op jagluiperds is by Hoedspruit gedoen waar die Weermag oor goed afgekampte en afgesonderde opleidingsgebiede beskik. Huidiglik is daar sowat 5000 springbokke by die militêre terrein in Bloemfontein. Dit word as een van die grootste troppe in Suid-Afrika beskou.

Die Weermag het verlede jaar ' $n$ groot bydrae tot natuur- en omgewingsbewaring gelewer. Miljoene sprinkane het 'n groot deel van Suid-Afrika se vrugbare oppervlakte bedreig. Die sprinkaanplaag, wat groot gedeeltes plaasweiding in die Oos-Kaap, Vrystaat, Wes-Transvaal, Karoo, Noordoos en Noordwes-Kaap besmet en beskadig het, is as die ergste in 30 jaar beskou.

Sowat 50 militêre voertuie afkomstig van die Leërgevegskool by Lohathla is beskikbaar gestel. Elke distrik se bestryding is deur die Boere en Weermaglede waargeneem wat met 3 tot 4 arbeiders die besmette gebiede met gifstof bespuit het. Goeie samewerking tussen die plaaslike gemeenskappe en die Weermag is verkry: motorhawens het met die herstel van Weermagvoertuie gehelp terwyl soldaat en boer rug aan rug teen die sprinkaanplaag geveg het. Sodoende het die Weermag weer eens sy rol as beskermer van die gemeenskap en omgewing bewys.

\section{Militêre terreine as bewaringsgebiede}

Alhoewel die Suid-Afrikaanse Weermag meer as 50 militêre terreine as bewaringsgebiede dwarsoor die land bestuur, word slegs drie daarvan hier behandel.

\section{Vhembe-natuurreservaat}

Vhembe is langs die Limpoporivier geleë, waar Zimbabwe, Botswana en die Republiek van Suid-Afrika aan mekaar grens. Dit word reeds sedert die vroeg 1900's deur die Weermag beheer. In 1967 was dit die eerste militêre terrein wat tot privaatnatuurreservaat verklaar is.

Vhembe bestaan uit 4 hoofplantgemeenskappe $\mathrm{nl}$. rivieroewerbos, vloedvlaktes, ranteveld en die sandveldplato. Wildsoorte op die terrein sluit rooibokke, bosbokke, waterbokke, koedoes, 


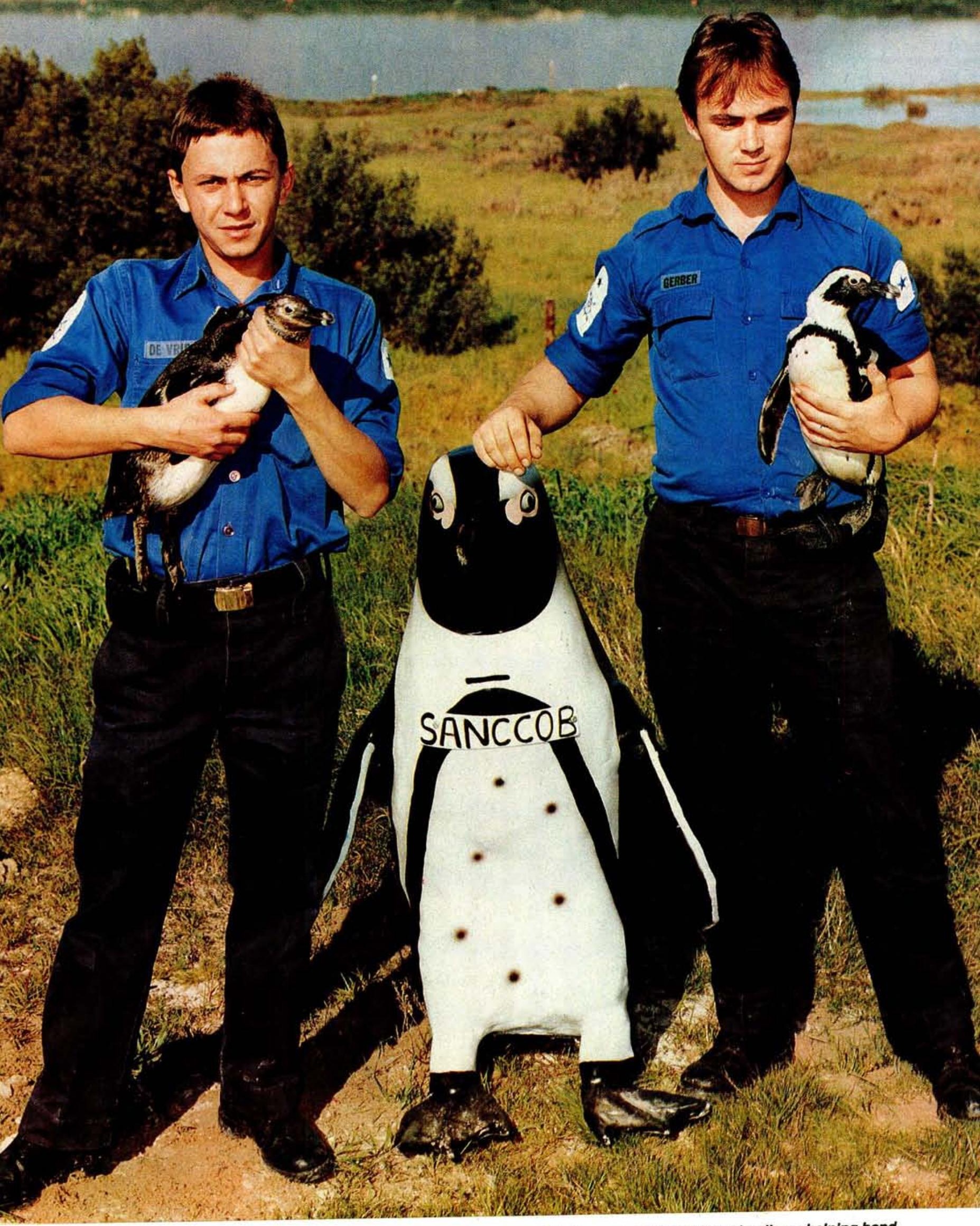

Twee bevare seemanne van die SA Vloot verleen hulp Twee bevare seeman vars Kaapse Plkkewyn by die met die bewaring van die skaars Kaapse Plk vewaring van Kusvoëls.
Two Able Seamen of the SA Navy lending a helping hand with the preservation of the rare Cape Penguin at the SA National Foundation for the Conservation of Coastal

Birds (SANCCOB). 


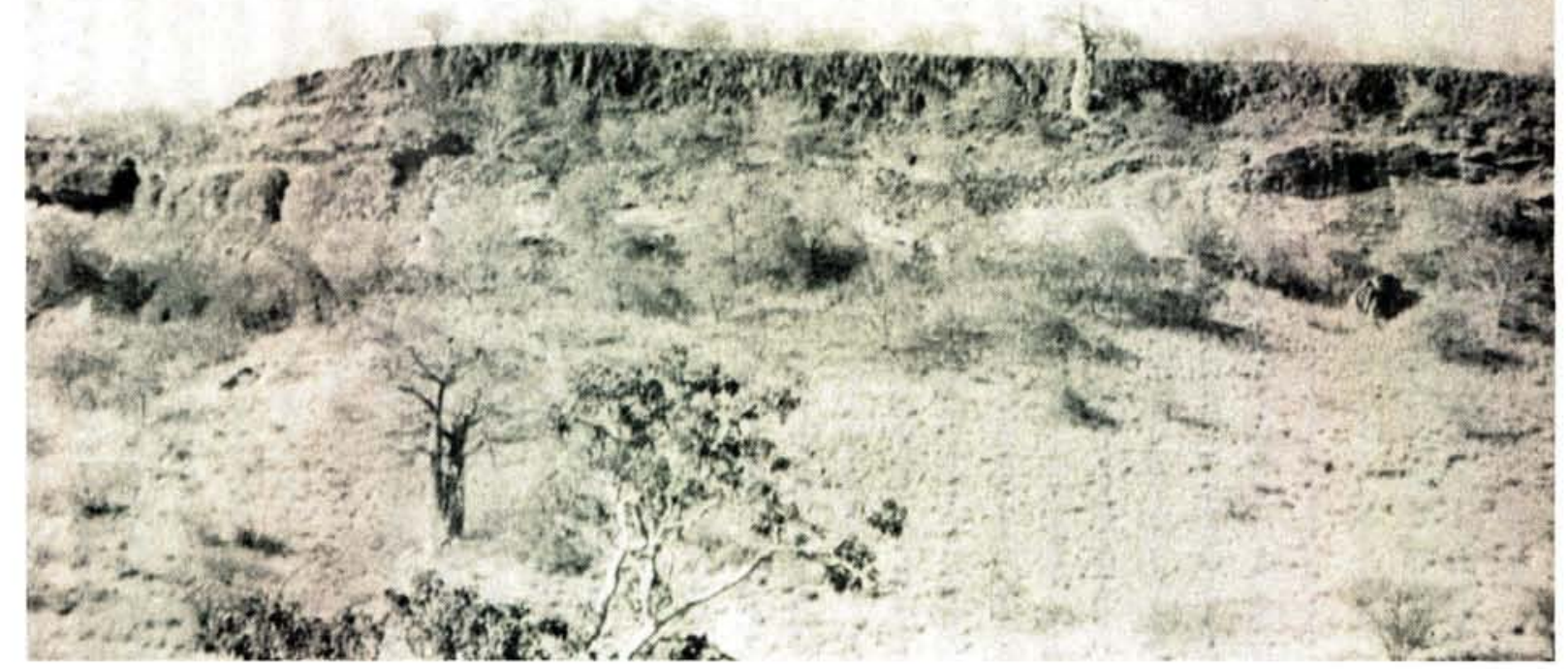

Die Mapungubwe-koppie is die terrein van argeologiese opgrawings van vondse wat tot 1000 jaar oud dateer. Dit is as Nasionale Gedenkwaardigheid verklaar.

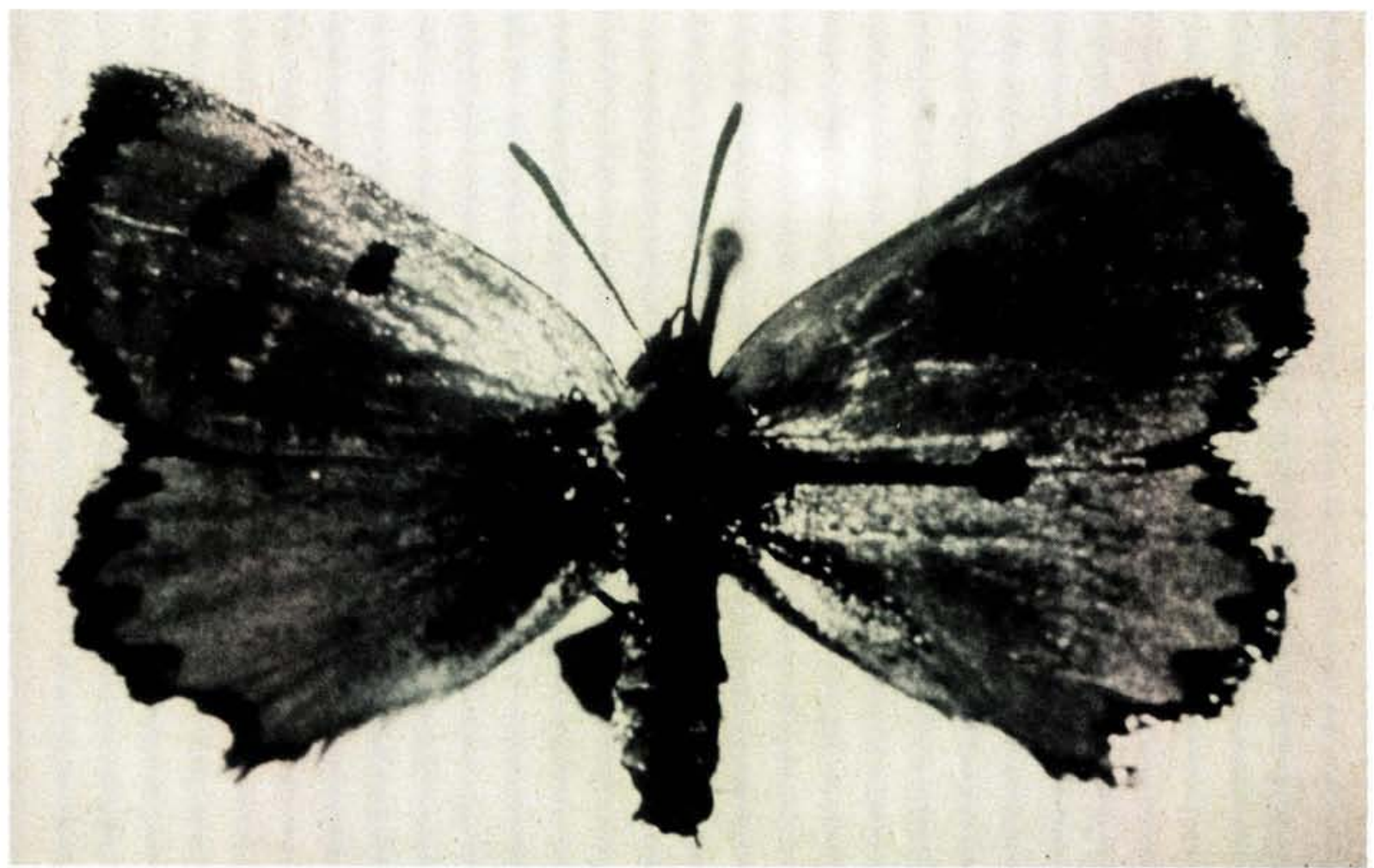

Die Heidelberg-opleidingsterrein is een van slegs twee vindplekke van die skaars Heidelberg-koperskoenlapper (Poecilitis aureus). Die terrein is as ' $n$ natuurerfenisterrein verklaar en die betrokke habitat word spesiaal beskerm. 
bontkwaggas, blouwildebeeste, elande, seekoeie, klipspringers, tropiese grysbokke, duikers en steenbokke in, terwyl olifante die gebied periodiek besoek. Verskeie roofdiere waaronder luiperds, kom ook hier voor.

Die natuurbewaringswaarde van Vhembe lê veral in die bewaring van ' $n$ verskeidenheid gemeenskappe binne die Mopanieveld, die steeds skaarser wordende rivieroewerbos, etlike skaars en bedreigde plant- en diersoorte en baie groot eksemplare van die riviertrosvy.

Ander belangrike verskynsels van bewaringsbelang is argeologiese opgrawings op die Mapungubwe-koppie wat as Nasionale Gedenkwaardigheid verklaar is, ' $n$ verskeidenheid sandsteenformasies en ' $n$ aantal Boesmantekeninge.

\section{Corbadraai-natuurreservaat}

Corbadraai (ongeveer 1300 ha groot) is omtrent $35 \mathrm{~km}$ noord van Pietersburg geleë. Die Roodewalbombaan, wat suid van die reservaat geleë is, is in 1966 deur die Weermag oorgeneem, terwyl die Corbadraaigedeelte in 1973 bygevoeg is. Corbadraai is deel van die veiligheidsgebied rondom die bombaan en is in 1979 as tweede militêre terrein tot privaatnatuurreservaat verklaar.

Tydens proklamasie het slegs koedoes, duikers en steenbokke as wildsoorte hier voorgekom. Sedertdien is rooibokke, blouwildebeeste, kameelperde, volstruise, bontkwaggas asook die skaars witrenosters, basterhartbeeste en bastergemsbokke hier hervestig. Tans word ondersoek ingestel na die moontlike aanwending van die hele bombaan as teelgebied vir skaars wildsoorte.

Gedurende 1983 is die wisseltrofee vir natuurbewaring in die Weermag aan hierdie terrein toegeken.

\section{Lugmagbasis Hoedspruit Natuurreservaat}

Hoedspruit is in die sewentigerjare deur die Weermag oorgeneem vir die ontwikkeling van 'n Lugmagbasis. Dit is hoofsaaklik die sekerheidsgebied van ongeveer 2000 ha buite om die basis en landingsbasis wat as reservaat bestuur word. Die terrein is in 1981 as die derde militêre terrein tot privaatnatuurreservaat verklaar.
Hoedspruit val binne die dorre laeveldstreek. Die veldtipe staan bekend as ' $n$ knoppiesdoring/ maroela savanna met immergroen bome langs die spruite. Die algemeenste boomsoorte in die gebied is knoppiesdoring, maroela, rooiboswilg, sekelbos en tambotie.

Met die oorname van die basis was die veld in ' $n$ baie swak toestand as gevolg van oorbeweiding. Om verdere agteruitgang te verhoed, was dit nodig om wildgetalle drasties te verminder.

Gedurende 1979 het rooibokke, koedoes, blouwildebeeste, waterbokke, bosbokke, bontkwaggas, kameelperde, duikers en steenbokke hier voorgekom. Sedertdien is witrenosters, basterhartbeeste, swartwitpense en njalas hier hervestig. Hoedspruit het een van die hoogste konsentrasies kameelperde per oppervlakeenheid in Suid-Afrika. Leeus, luiperds en jagluiperds word periodiek aangetref.

Twee tipes gronderosie kom in die reservaat voor, naamlik plaaterosie en slooterosie. Slooterosie word bekamp deur klipwalle in die slote te pak om sodoende die spoed van die water te breek en grondafsetting te bevorder. Plaaterosie word bekamp deur bo-grond in te ry en dit op die ontblote areas uit te sprei.

'n Brandprogram is vir ekologiese doeleindes belangrik aangesien dit ou dooie materiaal verwyder en nuwe groei stimuleer. Huidiglik word daar aan ' $n 5$ jaar rotasie brandprogram gewerk.

In die Suid-Afrikaanse Weermag se beleid tov natuur- en omgewingsbewaring speel bewusmaking ' $n$ belangrike rol. Derhalwe word Voortrekkers en skoolgroepe gereeld op staptoere in die reservaat geneem. Daar is ook ' $n$ uitkykpunt by een van die damme opgerig waar mense kan uitklim om die voël- en dierelewe te besigtig.

Lugmagbasis Hoedspruit het gedurende 1984 1985 en 1987 die wisseltrofee vir natuurbewa. ring in die Suid-Afrikaanse Weermag ontvang.

\section{Omgewingsbewaring en -opvoeding in die Suid-Afrikaanse Weermag}

Die Weermag is egter nie net by natuurbewaring op sy opleidingsterreine betrokke nie, maar ook by omgewingsbewaring in sy basisse. Basisse word netjies en skoon gehou asook verfraai. Baie bome en ander plante, veral inheems, word geplant. Sodoende word ' $n$ aangename werks- 


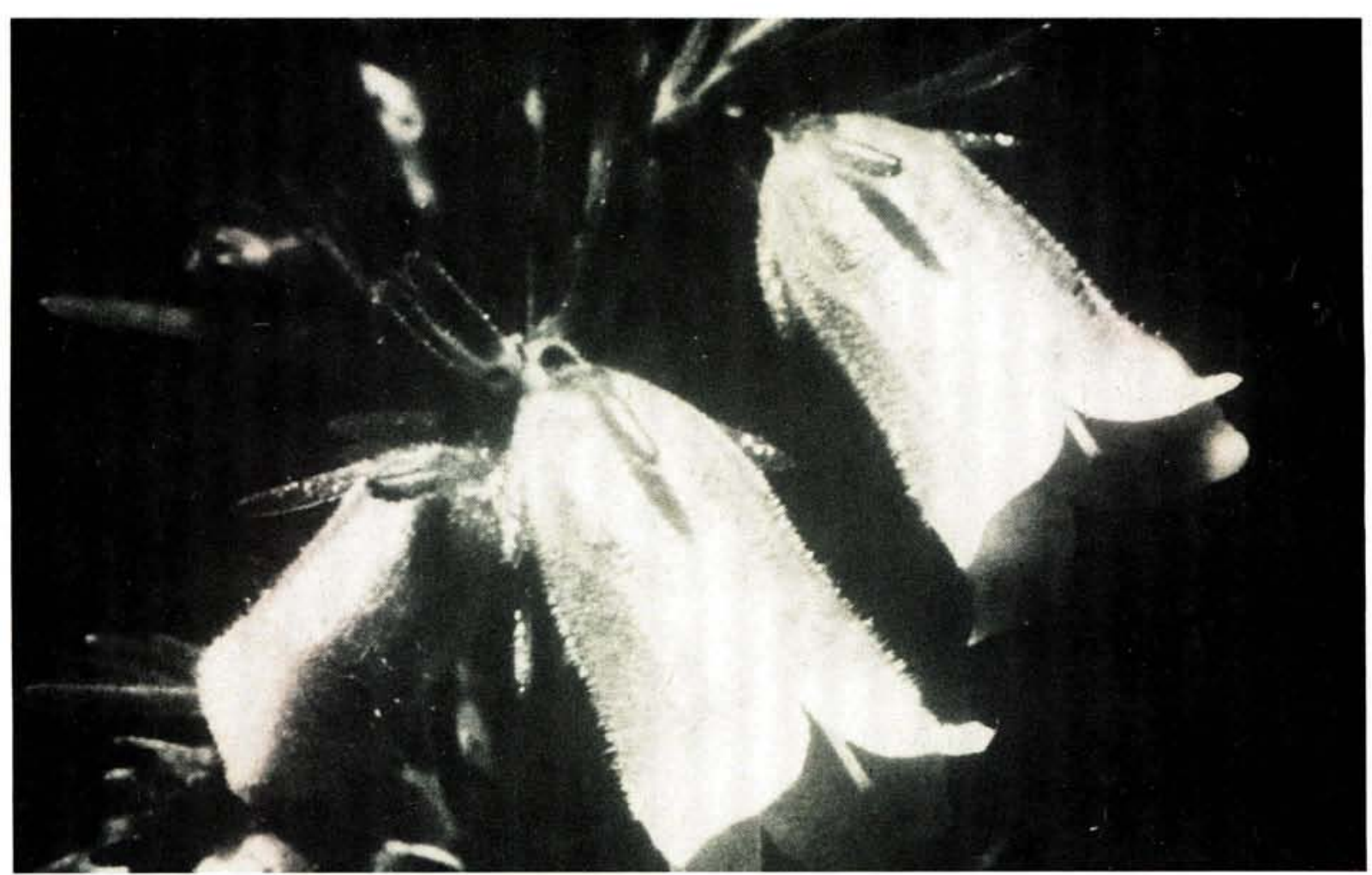

Die uiters skaars Erica heleogena ('n heidesoort) se enigste vindplek in die wêreld is die Klawervallei militêre gebied naby Simonstad. Die terrein is as 'n natuurerfenisterrein verklaar en die moeras waar die plant voorkom, word beskerm.

omgewing geskep wat produktiwiteit verhoog. Jaarliks word daar aan die Nasionale Omgewingsweek en die Nasionale Boomplantdag deelgeneem waartydens duisende inheemse bome al geplant is.

Netheid, verantwoordelike en selfbeheersde optrede en dissipline is deel van enige militêre tradisie. Die kweek van 'n positiewe gesindheid teenoor die natuurlike en mensgemaakte omgewing onder lede, bly vir die Suid-Afrikaanse Weermag ' $n$ belangrike en deurlopende opvoedingstaak vanweë die duisende nasionale dienspligtiges wat jaarliks opgeroep word. Daarsonder sou die hele funksie ekologiese dienste ook nie suksesvol uitgevoer kon word nie.

'n Belangrike aspek van omgewingsbewaring is dus bewusmaking. Dit word dmv video- en skyfiereekse, lesings, filmvertonings, uitstappies, uitstallings, plakkate en slagspreuke gedoen. Verskeie persone word aangewend om dié lesings, praatjies en vertonings aan te bied. Meestal word daar van gekwalifiseerde dienspligtiges, wat as natuurbewaringspersoneel in die Weermag werk, gebruik gemaak. Dikwels word persone van ander instansies soos die vier provinsiale natuurbewaringsafdelings, Suidwes-
Afrika Departement vir Natuurbewaring en Toerisme, die Nasionale Parkeraad, die Hou SuidAfrika Skoonvereniging, die Nasionale Veldtrust en universiteitspersoneel gevra om lesings aan te bied.

Twee wisseltrofeë (die Trust vir Bedreigde Natuurlewe se Wisseltrofee vir Natuurbewaring in die Suid-Afrikaanse Weermag en die Caltex-wisseltrofee vir Omgewingsbewaring in die SuidAfrikaanse Weermag) word ook jaarliks aan die eenhede, wat die meeste vordering met natuuren omgewingsbewaring getoon het, toegeken. Die Nasionale Veldtrust se wisseltrofee vir Omgewingsopvoeding in die SA Weermag sal vanaf 1988 toegeken word.

Die Suid-Afrikaanse Weermag is sedert 1981 aktief betrokke by die Hou Suid-Afrika Skoonvereniging en is op etlike plaaslik-geaffilieerde verenigings verteenwoordig.

\section{Slot}

Die Suid-Afrikaanse Weermag besef dat 'n gesonde ekosisteem van die uiterste belang vir die voortsetting van Suid-Afrika en sy mense is. 
Daarom word die bewaring en behoud van die natuurlike omgewing as deel van ' $n$ militêre tradisie beskou. Dit is die Weermag se verklaarde beleid "om die omgewing op sy terreine tot die beste van sy vermoë in sy natuurlike toestand te laat of daartoe te herstel". Gedurende die afgelope tien jaar het die Suid-Afrikaanse Weermag homself as een van die grootste bydraers tot natuur- en omgewingsbewaring in Suid-Afrika bewys en uit alle oorde word heelwat lof en erkenning daarvoor ontvang.
* Mev. W. Kleyn, Dipl. in Nasionale Joernalistiek is verbonde aan die Direktoraat Openbare Betrekkinge van die SA Weermag.
Bronne
1. Persoonlike onderhoude gevoer met Maj. S.K.B. Godschalk, Seksie Eko- logiese Dienste, Afdeling Logistiek.
2. Paratus, Augustus 1986, Kenners kyk na SAW se groot bydrae.
3. Paratus, Julie 1986, SA Weermag gryp in toe sprinkaanplaag toeslaan.
4. Paratus, Junie 1985, Die Weermag en Natuurbewaring.
5. Paratus, Junie 1984, Natuur word hier gered.
6. Die Beeld, 29 September 1987, Waar die vlinder en oorlogtenk saamleef. 